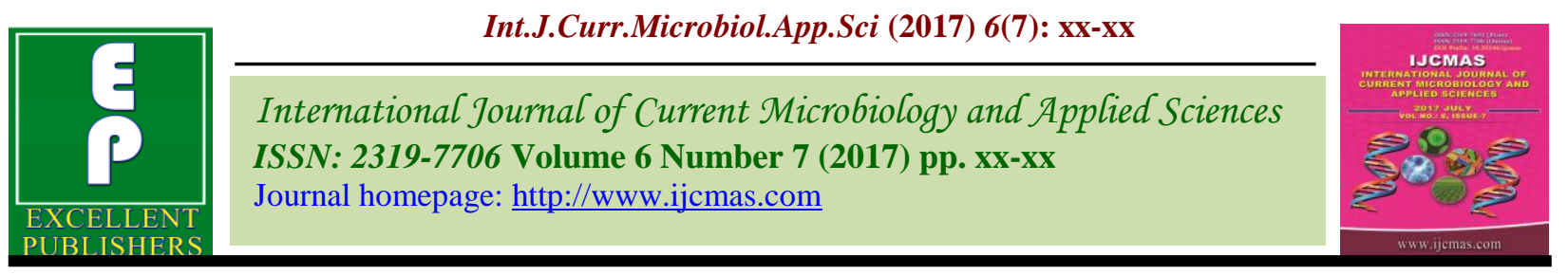

Original Research Article

https://doi.org/10.20546/ijcmas.2017.607.067

\title{
Optimization of Lactobacillus casei and Inulin Levels in the Preparation of Synbiotic Whey Beverage Using Response Surface Methodology
}

\author{
M. Dharani Kumar ${ }^{1 *}$, A.K. Beena ${ }^{2}$, Mohammed Davuddin Baig ${ }^{3}$ \\ ${ }^{1}$ National Dairy Research Institute, Karnal, Haryana, India \\ ${ }^{2}$ Department of Dairy Microbiology, College of Dairy Science and Technology, Mannuthy, \\ Kerala Veterinary and Animal Sciences University, Kerala, India \\ ${ }^{3}$ College of Dairy Science and Technology, Mannuthy, Kerala Veterinary and Animal Sciences \\ University, Kerala, India \\ *Corresponding author
}

\section{A B S T R A C T}

\begin{tabular}{|l|}
\hline K e y w o r d s \\
Synbiotics, \\
$\begin{array}{l}\text { Response Surface } \\
\text { Methodology, } \\
\text { Probiotics. }\end{array}$ \\
\hline Article Info \\
\hline $\begin{array}{l}\text { Accepted: } \\
\text { 04 June } 2017 \\
\text { Available Online: } \\
\text { 10 July } 2017\end{array}$ \\
\hline
\end{tabular}

Keywords

Synbiotics,

Response Surface

Methodology,

Probiotics.

10 July 2017
Synbiotics are the synergistic combination of probiotics and prebiotics which helps in accomplishment of health benefits in host. Whey is a nutrient rich by-product of dairy industry which is not being utilized properly and disposed. The present work is designed to standardize the procedure for preparation of synbiotic beverage utilizing whey. In this study Lactobacillus casei NCDC 298 was used as the probiotic organism and inulin was used as prebiotic. The level of inoculum and prebiotic was optimized using the Response Surface Methodology (RSM) (Design expert ${ }^{\circledR}$ software version 9.0.4.1). Accordingly the rate of inoculum and level of inulin was fixed as 1.53 and 0.69 per cent respectively. Based on sensory evaluation, the level of sugar and flavour emulsion was fixed as $11 \%$ and $0.03 \%$ respectively. Inulin supplemented pasteurized whey was inoculated with $1.53 \%$ of inoculum and kept for fermentation at $37^{\circ} \mathrm{C} / 16 \mathrm{~h}$. After fermentation, fixed levels of sugar and flavour emulsion was added and then stored under refrigeration temperature.

\section{Introduction}

Whey, the major by-product of dairy industry is being generated in huge quantities during production of paneer, cheese, casein, coprecipitates and shrikhand. It is an exceptional provenience of nutrients such as lactose $(5 \%)$, protein $(0.85 \%)$, minerals $(0.52 \%)$ and fat $(0.36 \%)$ and constitutes almost half of the milk total solids. It contains opulent proteins like $\beta$-lactoglobulin ( $\beta$-Lg), $\alpha$-lactalbumin $(\alpha-$ La) which has a biological value of 107 when compared to milk protein casein (77), egg (88) and soya proteins (59) (Jain et al., 2013). Globally 180 million tonnes (MT) of whey is being produced annually with a predicted annual increase of two per cent (Affertsholt, 2009).

Whey with its gigantic biological oxygen demand (40000-50000 ppm) has a huge polluting potential, disposal of whey as such do pose a threat to the environment (Hati et al., 2013). Stringent environmental 
regulations that are established globally demands the industries to have a viable and feasible way to dispose whey.

The association of probiotics and prebiotics in foods helps in accomplishment of additional health benefits than their presence alone. These combination containing foods are termed as 'Synbiotics'. According to Dhewa et al., (2014), the synergetic effect between probiotic organisms and prebiotic compounds could be effective in reducing colon carcinogenesis than their individual effect. Kumar et al., (2015) reported that consumption of probiotic fermented products lowers cholesterol levels. With an increasing awareness on diet health link, the demand for synbiotic foods is showing an outstanding growth rate in their consumption. Moreover, the technological advancements and clinically proven diverse health benefits adds advantage to these products.

\section{Materials and Methods}

Pasteurized buffalo milk from University Dairy Plant, Kerala Veterinary and Animal Sciences University (KVASU), Mannuthy was used for product development. Inulin was purchased from 'Brenntag connecting chemistry' company, India. Orange E-SPL (Sonarome) flavour emulsion was procured from the local super market, Thrissur. Lactobacillus casei having code number NCDC 298 was purchased from National Collection of Dairy Cultures (NCDC), Karnal. Lyophilized Lactobacillus casei culture of NCDC 298 culture was aseptically transferred separately into sterile skim milk (15lbs pressure $121^{\circ} \mathrm{C}$ for 15 minutes) and incubated at $37^{\circ} \mathrm{C}$ until coagulation. Three consecutive transfers were done daily for maximum activation of culture. Routine maintenance of these cultures was carried out by fortnightly transfer in sterilized whey. In between the transfers, cultures were kept at $4^{\circ} \mathrm{C}$.
The synbiotic whey beverage was prepared by incorporating Lactobacillus casei, inulin, sugar and flavour. The optimization of the levels of Lactobacillus casei and inulin in synbiotic whey drink was done by the Response Surface Methodology.

The prepared whey was filtered and standardized to a total solids content of 5.5 percent by adding pasteurised water. Optimized level of Inulin $(0.69 \% \mathrm{w} / \mathrm{v}$ of whey) was added to the whey at $60^{\circ} \mathrm{C}$ to ensure complete dissolution and avoid sedimentation.

Then whey was pasteurised at $72^{\circ} \mathrm{C} / 15 \mathrm{sec}$ to destroy pathogenic organisms present in it. Then it was cooled down to $40^{\circ} \mathrm{C}$ at which optimized level of L. casei i.e. $1.53 \%$ (w/v of whey) was added and kept for fermentation for $16 \mathrm{~h}$ at $37^{\circ} \mathrm{C}$.

The optimized levels of sugar and orange flavour at a level of $11 \%$ and $0.03 \%(\mathrm{w} / \mathrm{v}$ of whey) were added to fermented product respectively. The prepared product was packed in sterilized glass bottles and stored at refrigerated temperature. Flowchart for the preparation of synbiotic whey beverage is depicted in figure 1 .

\section{Results and Discussion}

Optimization of levels of Lactobacillus casei and inulin in synbiotic whey drink by Response Surface Methodology

Central Composite Rotatory Design (CCRD) of response surface methodology was used to optimize the levels of addition of Lactobacillus casei NCDC 298 and inulin in the synbiotic whey beverage prepared (Table 2 ). The maximum and minimum level of each ingredient was chosen based on the preliminary trials. The actual and coded values of two factors at five levels in the 
CCRD are shown in table 1 . The experimental design of 13 formulations consisted of four factorial points, four axial points and five replicates of the central point as given in table 1 .

Effect of the two factors on response values Validation of the fitted model

\section{Effect on pH}

The RSM estimated linear equation in terms of actual factors for predicting the effect of different variables on $\mathrm{pH}$ is as follows:

$\mathrm{pH}=6.92-2.66 *$ L. casei $\%-1.81 *$ Inulin $\%+0.78 *$ L. Casei $\% *$ Inulin $\%+0.54$ $*$ L. casei $\% 2+0.34 *$ Inulin $\% 2$

\section{Effect on acidity}

The RSM estimated linear equation in terms of actual factors for predicting the effect of different variables on acidity is as follows:

Acidity $=0.02+0.48 *$ L. casei $\%+0.36 *$ Inulin\% $\%$ - $0.18 *$ L. casei\%* Inulin\% $-0.09 *$ L. casei $\% 2-0.03 *$ Inulin $\% 2$

\section{Effect on Lactobacillus count}

The RSM estimated linear equation in terms of actual factors for predicting the effect of different variables on Lactobacillus count is as follows:
Lactobacillus count $=-11.00+18.90 * \mathrm{~L}$. casei $\%+9.55 *$ Inulin $\%+3.33 *$ L. casei $\% *$ Inulin\% $\%$ 4.98* L. casei\%2 - $4.89 *$ Inulin\%2

\section{Effect on colour and appearance}

The RSM estimated linear equation in terms of actual factors for predicting the effect of different variables on colour and appearance is as follows:

Colour and appearance $=2.02+3.55 * L$. casei $\%+11.63 *$ Inulin $\%-1.33^{*}$ L. casei\%* Inulin\%-0.83* L. casei\%2 - 7.19* Inulin\%2

\section{Effect on flavour}

The RSM estimated linear equation in terms of actual factors for predicting the effect of different variables on flavour is as follows:

Flavour $=1.51+3.57 *$ L. casei $\%+12.40 *$ Inulin\% $-1.63 *$ L. casei\% * Inulin\% $-0.83 *$ L. casei\%2 - 7.09* Inulin\%2

\section{Effect on overall acceptability}

The RSM estimated linear equation in terms of actual factors for predicting the effect of different variables on overall acceptability is as follows:

Overall acceptability $=2.33+3.67 * L$. casei $\%+10.66 *$ Inulin $\%-1.37 *$ L. casei\%* Inulin $\%-0.95^{*}$ L. casei\%2 - 6.41* Inulin\%2.

Table.1 The coded and actual levels of the two factors

\begin{tabular}{|l|c|c|c|c|c|}
\hline Factor & $\begin{array}{c}\text { Lower } \\
\text { limit }\end{array}$ & $\begin{array}{c}\text { Factorial } \\
\text { point }\end{array}$ & $\begin{array}{c}\text { Centre } \\
\text { coordinate }\end{array}$ & $\begin{array}{c}\text { Factorial } \\
\text { point }\end{array}$ & Higher limit \\
\hline $\begin{array}{l}\text { Lactobacillus } \\
\text { casei }(\%)\end{array}$ & 0.55 & 0.8 & 1.4 & 2 & 2.25 \\
\hline Inulin (\%) & 0.4 & 0.5 & 0.75 & 1 & 1.1 \\
\hline
\end{tabular}


Table.2 Central composite design matrix for two variables: Lactobacillus casei and inulin

\begin{tabular}{|c|c|c|}
\hline \multirow{2}{*}{$\begin{array}{c}\text { Standard } \\
\text { order }\end{array}$} & Factor 1 & Factor 2 \\
\cline { 2 - 3 } & A: Lactobacillus casei $(\%)$ & B: Inulin (\%) \\
\hline 1 & 0.8 & 0.5 \\
\hline 2 & 2 & 0.5 \\
\hline 3 & 0.8 & 1 \\
\hline 4 & 2 & 1 \\
\hline 5 & 0.55 & 0.75 \\
\hline 6 & 2.25 & 0.75 \\
\hline 7 & 1.4 & 0.4 \\
\hline 8 & 1.4 & 1.1 \\
\hline 9 & 1.4 & 0.75 \\
\hline 10 & 1.4 & 0.75 \\
\hline 11 & 1.4 & 0.75 \\
\hline 12 & 1.4 & 0.75 \\
\hline 13 & 1.4 & 0.75 \\
\hline
\end{tabular}

Fig.1 Flowchart for the preparation of synbiotic whey beverage

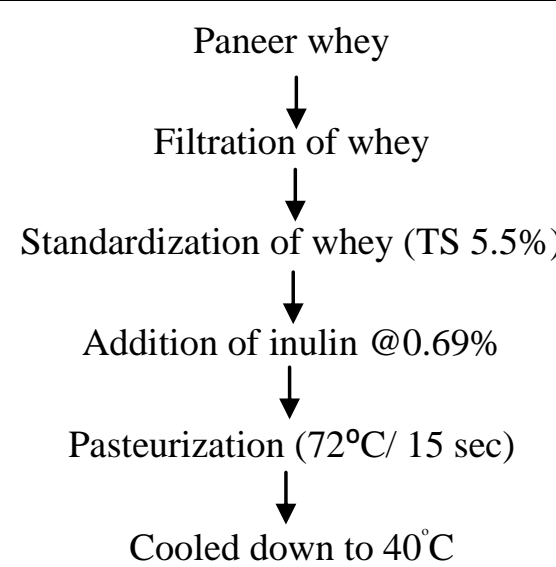

Inoculation of NCDC 298 culture @ 1.53\% maintained in whey<smiles>[13IH]</smiles>

Incubation at $37^{\circ} \mathrm{C} / 16 \mathrm{~h}$

Sugar addition @ $11 \%$ and addition of flavour @0.03\%

Storage at $5^{\circ} \mathrm{C}$ 
Table.3 Various responses of synbiotic whey drink prepared with different levels of Lactobacillus casei and inulin

\begin{tabular}{|c|c|c|c|c|c|c|c|c|}
\hline \multicolumn{9}{|c|}{ Responses } \\
\hline $\begin{array}{l}\text { Standard } \\
\text { order }\end{array}$ & pH & Acidity & $\begin{array}{c}\text { Lactobacillus } \\
\text { count } \\
\text { (in } 10^{8} \\
\text { dilution } \\
\text { cfu/ml) }\end{array}$ & $\begin{array}{c}\text { Color and } \\
\text { Appearance }\end{array}$ & Mouthfeel & Sweetness & Flavour & $\begin{array}{c}\text { Overall } \\
\text { acceptability }\end{array}$ \\
\hline 1 & 3.97 & 0.57 & 13 & 8.4 & 8.5 & 8.7 & 8.5 & 8.71 \\
\hline 2 & 3.92 & 0.59 & 14 & 8.7 & 8.57 & 8.5 & 8.57 & 8.6 \\
\hline 3 & 3.87 & 0.61 & 18 & 7.5 & 7.14 & 7.7 & 7.3 & 7.38 \\
\hline 4 & 3.95 & 0.58 & 11 & 8.5 & 8.1 & 8 & 8.1 & 8.3 \\
\hline 5 & 4.7 & 0.45 & 6 & 7.6 & 7.42 & 7.85 & 7.42 & 7.7 \\
\hline 6 & 3.9 & 0.59 & 15 & 7.35 & 7.37 & 7.7 & 7.37 & 7.36 \\
\hline 7 & 4.75 & 0.43 & 3 & 7.9 & 7.9 & 8 & 7.9 & 7.9 \\
\hline 8 & 3.91 & 0.59 & 14 & 8.75 & 8.5 & 8.59 & 8.5 & 8.65 \\
\hline 9 & 3.9 & 0.6 & 14 & 8.8 & 8.1 & 8.4 & 8.1 & 8.6 \\
\hline 10 & 3.8 & 0.61 & 13 & 8.1 & 7.8 & 8.2 & 7.8 & 8 \\
\hline 11 & 4.3 & 0.56 & 9 & 7.8 & 7.9 & 8 & 7.9 & 7.9 \\
\hline 12 & 3.89 & 0.6 & 13 & 8.6 & 8 & 8.2 & 8.7 & 8.2 \\
\hline 13 & 3.8 & 0.62 & 17 & 8.5 & 8.1 & 7.8 & 8.1 & 7.95 \\
\hline
\end{tabular}


Table.4 Intercept and significance of Regression coefficients and results of fitted quadratic Model for various responses of synbiotic whey beverage

\begin{tabular}{|c|c|c|c|c|c|c|c|c|}
\hline \multirow[b]{2}{*}{$\begin{array}{c}\text { Partial } \\
\text { coefficients }\end{array}$} & \multicolumn{8}{|c|}{ Responses } \\
\hline & pH & Acidity & $\begin{array}{c}\text { Lactobacillus } \\
\text { count } \\
\text { (in } 10^{8} \text { dilution } \\
\text { cfu/ml) }\end{array}$ & $\begin{array}{l}\text { Colour and } \\
\text { appearance }\end{array}$ & Mouthfeel & Sweetness & Flavour & $\begin{array}{c}\text { Overall } \\
\text { acceptability }\end{array}$ \\
\hline Intercept & 3.92 & 0.59 & 13.60 & 8.65 & 8.33 & 8.48 & 8.47 & 8.55 \\
\hline $\begin{array}{c}\text { A- } \\
\text { Lactobasillus } \\
\text { casei }\end{array}$ & $0.000 * *$ & $0.001 * *$ & $0.001 * *$ & $0.219 \mathrm{~ns}$ & $0.910 \mathrm{~ns}$ & $0.612 \mathrm{~ns}$ & $0.935 \mathrm{~ns}$ & $0.809 \mathrm{~ns}$ \\
\hline B-Inulin & $0.037 *$ & $0.041^{*}$ & $0.003 * *$ & $0.035^{*}$ & $0.187 \mathrm{~ns}$ & $0.122 \mathrm{~ns}$ & $0.205 \mathrm{~ns}$ & $0.022 *$ \\
\hline $\mathrm{AB}$ & $0.004 * *$ & 0.017* & $0.207^{\mathrm{ns}}$ & $0.189^{\mathrm{ns}}$ & $0.092^{\mathrm{ns}}$ & $0.075^{\mathrm{ns}}$ & $0.107^{\mathrm{ns}}$ & $0.093^{\mathrm{ns}}$ \\
\hline $\mathrm{A}^{2}$ & $0.000 * *$ & $0.002 * *$ & $0.003 * *$ & $0.02 *$ & $0.060^{\mathrm{ns}}$ & $0.002 * *$ & $0.020^{*}$ & $0.003 * *$ \\
\hline $\mathrm{B}^{2}$ & $0.350^{\mathrm{ns}}$ & $0.785^{\mathrm{ns}}$ & $0.305^{\mathrm{ns}}$ & $0.003 * *$ & $0.012 *$ & $0.001 * *$ & $0.003 * *$ & $0.001 * *$ \\
\hline Lack of fit & NS & NS & NS & NS & NS & NS & NS & NS \\
\hline $\begin{array}{l}\text { Model F } \\
\text { value }\end{array}$ & $80.95 * *$ & $26.27 * *$ & $80.09 * *$ & $6.87 * *$ & $4.12 * *$ & $9.87 * *$ & $6.0 * *$ & $10.15^{* *}$ \\
\hline $\mathrm{R}^{2}$ & 0.97 & 0.91 & 0.98 & 0.71 & 0.56 & 0.79 & 0.69 & 0.79 \\
\hline Press & 0.13 & 0.012 & 19.19 & 3.20 & 2.72 & 0.40 & 2.37 & 1.30 \\
\hline $\begin{array}{l}\text { Adequate } \\
\text { precision }\end{array}$ & 27.95 & 15.59 & 29.72 & 6.62 & 5.4 & 8.16 & 6.17 & 8.3 \\
\hline
\end{tabular}

**- significant at one percent level, * significant at five percent level, NS/ns- Not significant 
Table.5 Constraints and criteria for optimization of synbiotic whey beverage

\begin{tabular}{|l|c|c|c|}
\hline Constraint & Goal & Lower limit & Upper limit \\
\hline $\begin{array}{l}\text { Lactobaillus casei } \\
(\%)\end{array}$ & In range & 0.8 & 2 \\
\hline Inulin (\%) & In range & 0.5 & 1 \\
\hline pH & In range & 3.8 & 4.75 \\
\hline Acidity & In range & 0.43 & 0.62 \\
\hline $\begin{array}{l}\text { Lactobacillus } \\
\text { count }\end{array}$ & Maximize & 3 & 18 \\
\hline $\begin{array}{l}\text { Colour and } \\
\text { appearence }\end{array}$ & Maximize & 7.35 & 8.8 \\
\hline Mouthfeel & Maximize & 7.14 & 8.57 \\
\hline Sweetness & Maximize & 7.7 & 8.7 \\
\hline Flavour & Maximize & 7.3 & 8.7 \\
\hline $\begin{array}{l}\text { Overall } \\
\text { acceptability }\end{array}$ & Maximize & 7.36 & 8.71 \\
\hline
\end{tabular}

Table.6 Solutions obtained after response surface analysis

\begin{tabular}{|l|c|c|c|}
\hline Sol. No. & Lactobaillus casei $(\boldsymbol{\%})$ & Inulin (\%) & Desirability \\
\hline 1 & 1.53 & 0.69 & 0.85 \\
\hline 2 & 1.99 & 0.82 & 0.566 \\
\hline
\end{tabular}


Table.7 Predicted values for the responses of synbiotic whey drink by the design expert RSM software for the suggested optimized solutions

\begin{tabular}{|c|c|c|c|c|c|c|c|c|}
\hline $\begin{array}{l}\text { Sol. } \\
\text { No. }\end{array}$ & pH & Acidity & $\begin{array}{c}\text { Lactobacillus } \\
\text { count } \\
\left(\log _{10} \mathrm{cfu} / \mathrm{ml}\right)\end{array}$ & $\begin{array}{c}\text { Color and } \\
\text { Appearan } \\
\text { ce }\end{array}$ & Mouthfeel & Sweetness & Flavour & $\begin{array}{c}\text { Overall } \\
\text { acceptability }\end{array}$ \\
\hline 1 & 3.8 & 0.61 & 16.9 & 8.31 & 7.92 & 8.07 & 8.03 & 8.03 \\
\hline
\end{tabular}

Table.8 Verification of the predicted value

\begin{tabular}{|l|c|c|c|c|c|c|c|c|}
\hline Values & pH & Acidity & $\begin{array}{c}\text { Lactobacillus } \\
\text { count } \\
\text { (in 10 dilution } \\
\text { cfu/ml) }\end{array}$ & $\begin{array}{c}\text { Color and } \\
\text { Appearanc } \\
\text { e }\end{array}$ & Mouthfeel & Sweetness & Flavour & $\begin{array}{c}\text { Overall } \\
\text { acceptability }\end{array}$ \\
\hline $\begin{array}{l}\text { Predicted } \\
\text { value }\end{array}$ & 3.8 & 0.61 & 16.9 & 8.31 & 7.92 & 8.07 & 8.03 & 8.03 \\
\hline $\begin{array}{l}\text { Observed } \\
\text { value }\end{array}$ & $3.8 \pm 0.02$ & $0.61 \pm 0.32$ & $17.2 \pm 0.33$ & $8.29 \pm 0.05$ & $7.97 \pm 0.11$ & $7.98 \pm 0.13$ & $8 \pm 0.09$ & $8 \pm 0.91$ \\
\hline $\mathrm{t}_{\alpha}$ & $1^{\mathrm{ns}}$ & $1^{\mathrm{ns}}$ & $0.79^{\mathrm{ns}}$ & $0.65^{\mathrm{ns}}$ & $0.66^{\mathrm{ns}}$ & $0.50^{\mathrm{ns}}$ & $0.78^{\mathrm{ns}}$ & $0.77^{\mathrm{ns}}$ \\
\hline
\end{tabular}

ns- Not significant 
Fig.2 Response surface plot relating to $\mathrm{pH}$ scores as influenced by level of Lactobacillus case $i$ and inulin

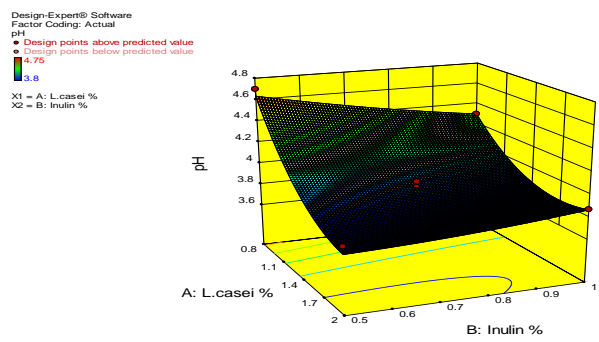

Fig.3 Response surface plot relating to acidity scores as influenced by level of Lactobacillus case $i$ and inulin

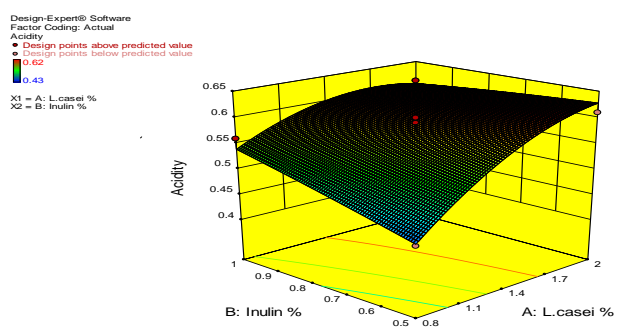

Fig.4 Response surface plot relating to Lactobacillus scores as influenced by level of Lactobacillus casei and inulin

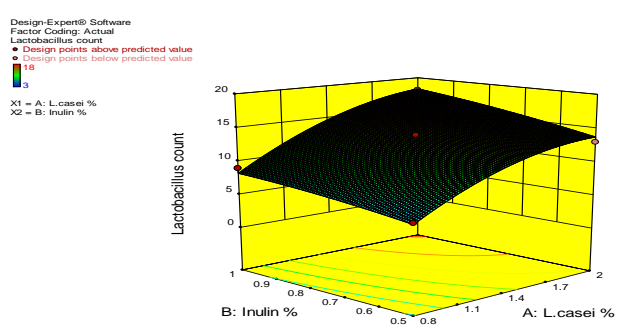

Fig.5 Response surface plot relating to colour and appearance scores as influenced by level of Lactobacillus case $i$ and inulin

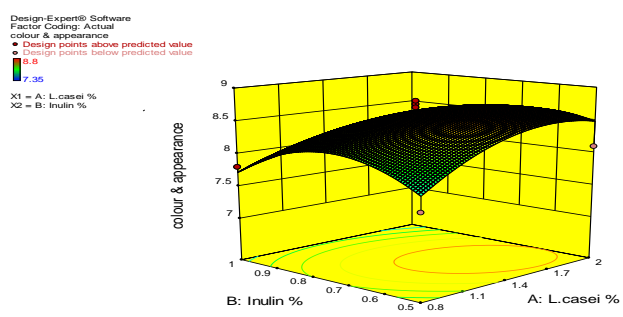

Fig.6 Response surface plot relating to mouthfeel scores as influenced by level of Lactobacillus casei and inulin

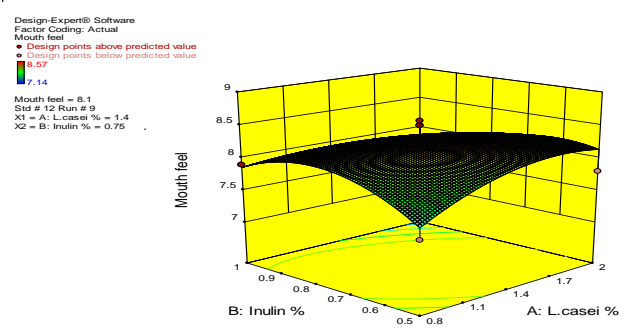

Fig.7 Response surface plot relating to sweetness scores as influenced by level of Lactobacillus casei and inulin

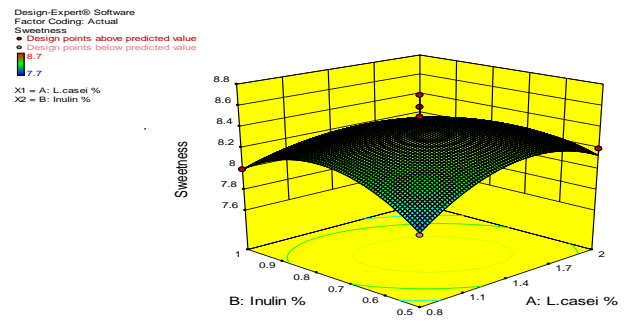

Fig.8 Response surface plot relating to flavour scores as influenced by level of Lactobacillus casei and inulin

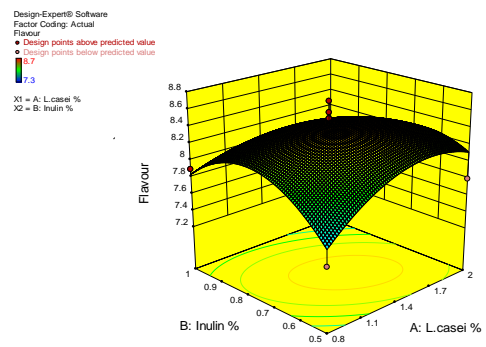

Fig.9 Response surface plot relating to overall acceptability scores as influenced by level of Lactobacillus casei and inulin

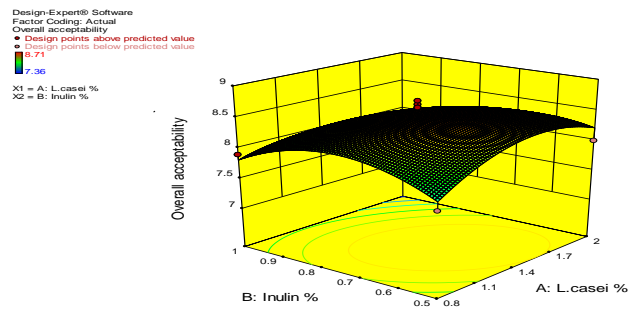




\section{Optimization procedure and verification of results}

The level of Optimised contents of Lactobacillus casei and inulin to be used in synbiotic whey drink was found out using the numerical optimization technique. The response goals for each factor are given in table 5. The protocol of maximum sensory scores (colour and appearance, flavour, mouthfeel, sweetness, overall acceptability), Lactobacillus count and Lactobacillus casei, inulin, $\mathrm{pH}$, acidity in the range were desired for the optimization of different levels of ingredients for the development of synbiotic whey drink (Table 4). The response surface methodology produced optimized solutions are shown in table 6 .

The predicted response scores for the optimized solutions are presented in table 7 . The product was prepared by the provided optimized solution which is having desirability of 0.836 . The synbiotic whey drink was studied for the responses and results obtained are presented in table 8 .

The interactive effect of L. casei NCDC 298 and inulin (Fig. 2) has shown increase on $\mathrm{pH}$ values. Such significant lowering effect on $\mathrm{pH}$ in lassi prepared with L. helviticus incorporated with inulin has been reported (Sharma et al., 2016). The interactive effect of $\mathrm{pH}$ was concomitant with that of the acidity observed in this study. From the results (Fig. 3), increase in addition of inulin from 0.75 to 1.1 by keeping level of inoculum constant (1.4\%) slight decreased in acidity values observed. This could be attributed to the neutralizing ability of inulin as earlier reported by Klose and Sjonvall (1983). Increase in level of inulin by keeping level of inoculum L. casei NCDC 298 constant $(1.4 \%)$ has shown increase in growth of $L$. case $i$ NCDC 298 (Fig. 4). This could be due to prebiotic effect of inulin. Similar stimulatory effect of inulin on $L$. casei was observed by Crisisco et al., (2010) in synbiotic ice cream. Representation of the interaction among the two different variables and their effect on colour and appearance of the synbiotic whey beverage are depicted in three dimensional surface plots (Fig. 5) From figure 5 it is clear that when Lactobacillus casei was kept constant (1.4\%) the addition of inulin showed gradual increase in the colour and appearance to a certain level then a sudden reduction while addition of Lactobacillus casei by keeping inulin constant $(0.75 \%)$, showed constant change in colour and appearance values.

The addition of Lactobacillus casei and inulin exhibited significant increase in the colour and appearance of the synbiotic whey beverage. As per table 3, increase in level of addition inulin by keeping L. casei NCDC 298 constant (1.4\%), significant decrease in colour and appearance scores was observed. This could be associated with the denaturation of inulin which in turn changes the colour and appearance. The adverse impact of inulin on the colour and appearance in fermented food products has been reported (Brasil et al., 2011). Higher mouth feel scores are observed by increase in addition of inulin by keeping L. casei NCDC 298 level constant (Fig. $6)$. Fat is a major constituent that contributes to mouthfeel of dairy products. Coussement (1999) reported that when inulin used as a fat replacer, $0.25 \mathrm{~g}$ of inulin was capable of replacing $1 \mathrm{~g}$ of fat in foods. This fat replacing capacity of inulin could be a reason for enhanced mouth feel. No significant changes in sweetness scores were seen in all the tested concentrations of inulin and all tested level of $L$. casei NCDC 298 (Fig. 7). This could be because of other sensory parameters which gained more preference rather than sweetness. Similar effect of sweetness on flavour also reported by Gover and Fugardi (1992) in flavoured beverages. No significant changes in flavour scores seen in all the tested concentrations of inulin and all tested level of L. casei NCDC 298 (Fig. 8). From this observation it can be assumed that increase in acidity values would have adversely affected the flavour. Ott et al., (2000) also reported the adverse effect of acidity on flavour scores. Increase in addition of inulin levels by keeping level of inoculum constant $(1.4 \%)$ has found to be increasing the overall acceptability (Fig. 9). This could be because of inulin which has the 
ability to improve the sensory scores. The similar effect of inulin in dairy foods earlier also reported (Frank, 2002).

In conclusion, Central Composite Rotatory Design (CCRD) of Response Surface Methodology (RSM) was used for the optimization of levels of probiotic and prebiotic in the synbiotic whey beverage. The response variables used were $\mathrm{pH}$, acidity, probiotic count and the sensory characteristics: colour and appearance, mouth feel, flavour, sweetness and overall acceptability. Coefficient of determination (R2) ranged from $56 \%$ to $98 \%$ for all the attributes and the Adequate Precision Value (APV) came in the range of 5.4 to 27.95. From the models, the optimum level of Lactobacillus casei NCDC 298 and inulin to achieve the predicted maximum response values were found to be 1.53 and 0.69 per cent respectively where sugar and flavour levels were added @ 11 and 0.03 per cent respectively.

\section{References}

Affertsholt, T. 2009. International whey market overview. In: proceedings The ADPI/ABI Annual Conference. 26th to 28th April, 2009, Chicago. The American Dairy Products Institute (ADPI) and American Butter Institute (ABI).

Brasil, J.A., Silveira, K.C.D., Salgado, S.M., Livera, A.V.S., Faro, Z.P.D. and Guerra, N.B. 2011. Effect of the addition of inulin on the nutritional, physical and sensory parameters of bread. Brazilian J. Pharm. Sci. 47(1): 185-191.

Coussement, P.A. 1999. Inulin and oligofructose: safe intakes and legal status. The J. Nutr. 129(7): 1412S-1417S.

Criscio, T., Fratianni, A., Mignogna, R.,
Cinquanta, L., Coppola, R., Sorrentino, E. and Panfili, G. 2010. Production of functional probiotic, prebiotic, and synbiotic ice creams. J. dairy Sci. 93(10): 4555-4564.

Dhewa, T., Pant, S. and Mishra, V. 2014. Development of freeze dried synbiotic formulation using a probiotic strain of Lactobacillus plantarum. J. food Sci. and Technol. 51(1): 83-89.

Franck, A. 2002. Technological functionality of inulin and oligofructose. Br. J. of Nutr. 87(S2): S287-S291.

Gover, R. and Fugardi, C. 1992. The effect of color on thirst quenching, sweetness, acceptability and flavor intensity in fruit punch flavored beverages. J. Food Quality. 15(1): 19-38.

Hati, S., Prajapati, J.B., Surajith, M. and Kaushik, K. 2013. Biofunctional Whey based beverages. Indian Dairyman. 65(5): 62-69.

Jain, S., Gupta, R. and Jain, S. 2013. Development of Low Cost Nutritional Beverage from Whey. IOSR J. Environ. Sci. 5(1): 73-88.

Klose, R.E. and Sjonvall, R.E. 1983. Low-calorie, sugar-free chewing gum containing polydextrose. Adv. J. of Food Sci. and Technol. 4: 963-965.

Kumar, A., Tomer, V., Kaur, A. and Joshi, V.K. 2015. Synbiotics: A culinary Art to Creative Health Foods. Int. J. Food and Fermentation Technol. 5(1): 1-14.

Ott, A., Hugi, A., Baumgartner, M. and Chaintreau, A. 2000. Sensory investigation of yogurt flavor perception: Mutual influence of volatiles and acidity. $J$. of Agric. and Food chem. 48(2): 441-450.

Sharma, S., Sreeja, V. and Prajapati, J.B. 2016. Development of synbiotic lassi containing honey: Studies on probiotic viability, product characteristics and shelf life. Indian J. Dairy Sci. 69(2):148-153.

\section{How to cite this article:}

Dharani Kumar, M., A.K. Beena, Mohammed Davuddin Baig. 2017. Optimization of Lactobacillus casei and Inulin Levels in the Preparation of Synbiotic Whey Beverage Using Response Surface Methodology. Int.J.Curr.Microbiol.App.Sci. 6(7): 558-568. doi: https://doi.org/10.20546/ijcmas.2017.607.067 